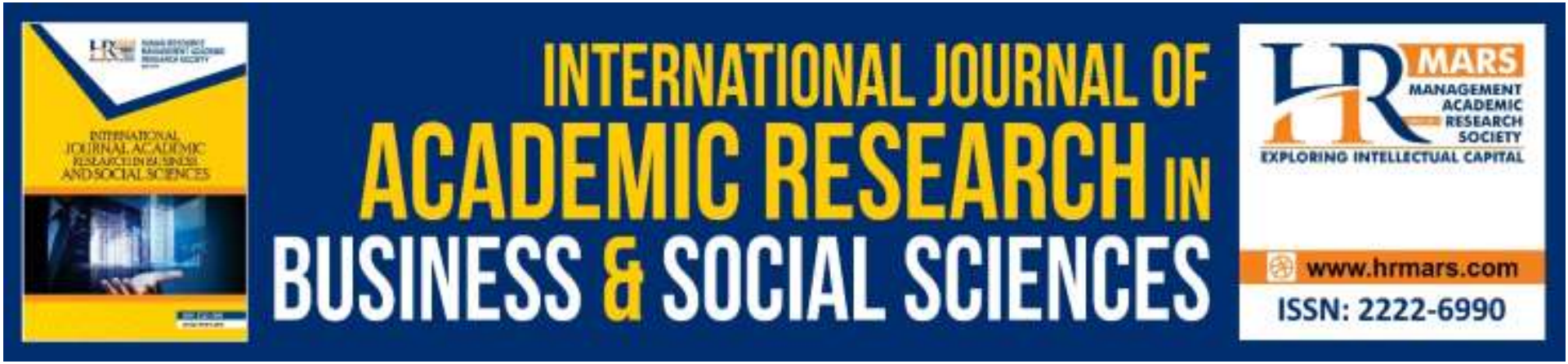

\title{
The Achievements in Acquiring Kadazandusun Language with Multimedia Assistance through Cooperative Learning and Individual Learning at Lower Secondary Level
}

Julita Norjietta Binti Taisin, Nordiana Binti Hamzah, Ani Binti Omar, Rosliah Kiting

To Link this Article: http://dx.doi.org/10.6007/IJARBSS/v9-i9/6379

DOI: 10.6007/IJARBSS/v9-i9/6379

Received: 03 August 2019, Revised: 30 August 2019, Accepted: 29 August 2019

Published Online: 28 September 2019

In-Text Citation: (Taisin, Hamzah, Omar, \& Kiting, 2019)

To Cite this Article: Taisin, J. N. B., Hamzah, N. B., Omar, A. B., \& Kiting, R. (2019). The Achievements in Acquiring Kadazandusun Language with Multimedia Assistance through Cooperative Learning and Individual Learning at Lower Secondary Level. International Journal of Academic Research in Business and Social Sciences, 9(9), 887-897.

Copyright: (C) 2019 The Author(s)

Published by Human Resource Management Academic Research Society (www.hrmars.com)

This article is published under the Creative Commons Attribution (CC BY 4.0) license. Anyone may reproduce, distribute, translate and create derivative works of this article (for both commercial and non-commercial purposes), subject to full attribution to the original publication and authors. The full terms of this license may be seen at: http://creativecommons.org/licences/by/4.0/legalcode

\section{Vol. 9, No. 9, 2019, Pg. 887 - 897}




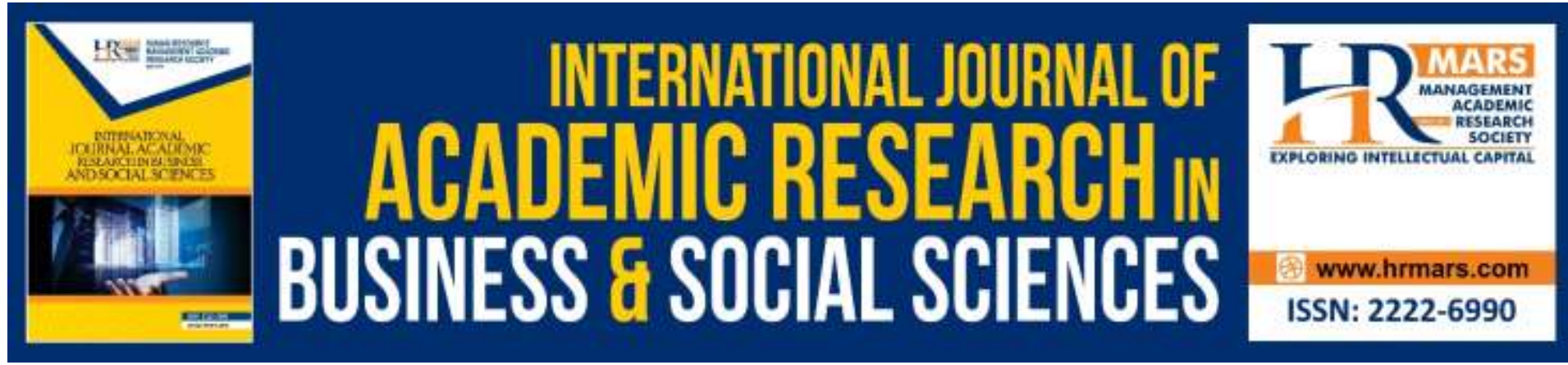

\title{
The Achievements in Acquiring Kadazandusun Language with Multimedia Assistance through Cooperative Learning and Individual Learning at Lower Secondary Level
}

\author{
Julita Norjietta Binti Taisin, Nordiana Binti Hamzah, Ani Binti \\ Omar, Rosliah Kiting \\ Faculty of Languages and Communication, Universiti Pendidikan Sultan Idris Tg.Malim \\ Perak, Malaysia. \\ Email :norjietta@fbk.upsi.edu.my,tjietta@yahoo.com.my
}

\begin{abstract}
This research aims to analyze the achievements of cooperative learning and individual learning based on the usage of multimedia. The quantitative approach is the methodology used for this research. Pre test and post test are used, involving the control group and treatment group. The pre test and post test data are done through percentage calculation. Results of research shows that the teaching and learning process delivered using mutilmedia materials; with a combination of texts, graphics, audio, videos, and animation through cooperative learning are able to improve the understanding of students with different learning abilities from $75 \%$ to $97 \%$. In conclusion, cooperative learning; assisted by multimedia elements contributes to the achievement of students compared to individual learning. Using audio visual helps students to understand and master the lessons. In addition, the implication of the research shows that cooperative learning, assisted by multimedia elements consist of leadership practices with social skills, besides practicing respect and responsibility. This is especially highlighted by students with higher level skills, by leading and guiding the group members. This is not the case in individual learning; as the understanding of the delivered information depends completely on the reasoning of the students themselves.
\end{abstract}

Keywords: Cooperative, Individuals, Multimedia, Teaching and Learning, and Kadazandusun.

Introduction

There are three ethic languages offered at public schools; namely Kadazandusun, Iban, and Senai. This is due to Chinese and Tamil languages being offered as additional subjects at schools. Currently, all the three mother tongue languages are categorized as elective subjects in schools. (Ethnic Language Unit, 2010). 
The Kadazandusun language is offered in schools in Sabah. It is a language spoken by the Kadazandusun community of Sabah (Ethnic Language Unit, 2010). According to Julita, Ahmed, Majid, \& Zin, (2016), lack of studies regarding Kadazandusun language from the perspectives of multimedia material usage based on certain models, and methods has become one of the many hurdles faced. This causes lack of ideas to improve the teaching and learning, especially in understanding the relationship between knowledge, teaching, and students' learning.

The current Education Theory focuses towards a more challenging paradigm, and is student centered in order to encourage them to think creatively, as well as being able to solve problems (Bates, 2010). It also emphasizes that, using technology in teaching and learning could create opportunities for students to improve their ability in solving problems, besides being able to think more critically. According to Kagan (2006), cooperative learning is one of the teaching technique which motivates and encourages active students' participation. It creates opportunities and potential for students to gain knowledge, besides always working together to achieve a common objective. According to Jamalludin \& Zaidatun (2003), the usage of multimedia elements enable teaching to be more consistent, increases the motivation and focus of students, satisfies the need for various learning styles, saves time, provides flexible learning time, in addition to having cheaper and safer learning method if students are doing experiments. The research by Norjietta (2016); Ahmed, Umrani, Qureshi, \& Samad, (2018) found that using multimedia in teaching and learning helps students to understand subjects, besides attracting their interests because using various multimedia elements helps students to understand techniques such as drilling, singing and others through cooperative or collaborative learning methods.

Previous researches have been used as guidance for this study. Although the gap in previous researches do not focus on Kadazandusun language teaching; it could provide an early description related to the cooperative learning, assisted by multimedia elements in teaching and learning processes.

\section{Research Objective}

The objective of this research is to analyse the achievements between cooperative elarning and individual learning based on the usage of multimedia materials.

\section{Problem Statement}

The lack of researches regarding Kadazandusun language from the perspective of multimedia material application; based on certain models or methods is one of the factor for this research to be done. This is in line with Tajib (2011); Ahmed, Isa, Majid, Zin, \& Amin. (2017). who mentions that without researches ideas to improve teaching and learning would be limited, especially in understanding the relationship between knowledge and, teaching and learning of students. Thus, such researches should be done with the hope to identify weaknesses or strengths and eventually rectifying or improving them.

The excisting Kadazandusun language teachers are also teaching other subjects such as Malay Language, English Language, Science, Visual Arts, Mathematics and others. This situation clearly provides some constraints in teaching aspects, especially in the application of multimedia (Norjietta, 2017). In accordance to that, Kagan (2006) mentions; cooperative learning is one of the teaching techniques which motivates and involves students actively. Thus, a teaching approach which is not well-planned from the aspects of students' 
involvement; would fail to create students who would be able to co-operatively achieve the determined objectives. The cooperative learning method provides such opportunities and potentials for students to gain knowledge as it is a well-planned approach.

Meanwhile, students who are weak in constructing sentences, grammar, writing essays in language subjects would contribute to the decline of academic achievements in school. Therefore, it is a fact that the integration of multimedia elements could reduce this constraints. This is in line with the research by Johan (2010), that there was an $80 \%$ achievement of students from rural area of Kudat district in Sabah; in understanding, interest, and mastery of learning through the application of WEDPI by teachers during teaching and learning processes.

\section{Methodology}

The quantitative approach is applied in this research. According to Najib (2003), the quantitative method enables the researchers to understand the overall research scope with small number of samples. The quantitative method was chosen based on data analysis, scores of both pre and post test using percentages obtained through test papers. The data analysis based on grades and scores of percentages are categorized based on achievements, as following:

2016 New Range of Examination and Test Marks Grades
\begin{tabular}{ccc}
\hline Range & Grade & Level of Achievement \\
\hline $80-100$ & A & Excellent \\
\hline $65-79$ & B & Good \\
\hline $50-64$ & C & Satisfactory \\
\hline $40-49$ & D & Achieved Minimum Level \\
\hline $0-39$ & E & Has Not Achieved Minimum Level \\
\hline & & (Malaysian Education Ministry, 2016)
\end{tabular}

To obtain the reliability index of the instruments, researchers did a pilot tests using worksheet based on software packages (multimedia elements) which were available in text book. Ther reseachers went to the schools to get help and assistance from the Headmaster, Senior Assistant and the Panel Head of the Kadazandusun Language subject. The subject teacher implemented the teaching based on teaching steps prepared using topics given and only used the audio section, without text book. 75 students sat for pre and post test with an involvement of $93.7 \%$ samples who answered both tests.

The questions in the worksheet for pre test and post test were built in line with the topic taught, which was Topic: Bombon (Audio 1: Page 3 , Text Book). The research samples from both groups were involved in the teaching and learning process for two weeks; 150 minutes (5 lessons). The teachers from the schools involved used the multimedia materials of selected topic; based on the teaching and learning objectives of Kadazandusun Language according to the lesson plan. 


\section{Result}

Achievement of Students Using Multimedia Materials Individually.

The achievement of students using multimedia materials individually (Class 2A1)

The Distribution of Individual Pre Test Scores (Table 1)

\begin{tabular}{|c|c|c|c|}
\hline Item & Number of Students & PERCENTAGE/ACHIEVEMENT & GRADE \\
\hline 1 & 1 & $97 \%$ & A \\
\hline 2. & 2 & $91 \%$ & A \\
\hline 3. & 1 & $89 \%$ & A \\
\hline 4 & 1 & $86 \%$ & A \\
\hline 5 & 2 & $85 \%$ & $A$ \\
\hline 6 & 1 & $79 \%$ & $\mathrm{~B}$ \\
\hline 7 & 1 & $78 \%$ & B \\
\hline 8 & 1 & $77 \%$ & $\mathrm{~B}$ \\
\hline 9 & 3 & $76 \%$ & $\mathrm{~B}$ \\
\hline 10 & 1 & $75 \%$ & B \\
\hline 11 & 1 & $72 \%$ & B \\
\hline 12 & 1 & $71 \%$ & B \\
\hline 13 & 1 & $68 \%$ & B \\
\hline 14 & 2 & $67 \%$ & $\mathrm{~B}$ \\
\hline 15 & 1 & $66 \%$ & $B$ \\
\hline 16 & 3 & $65 \%$ & $B$ \\
\hline 17 & 1 & $61 \%$ & $C$ \\
\hline 18 & 2 & $60 \%$ & $C$ \\
\hline 19 & 1 & $57 \%$ & $C$ \\
\hline 20 & 2 & $56 \%$ & $C$ \\
\hline 21 & 1 & $53 \%$ & $C$ \\
\hline 22 & 1 & $51 \%$ & $C$ \\
\hline 23 & 1 & $37 \%$ & $E$ \\
\hline 24 & 1 & $27 \%$ & $E$ \\
\hline
\end{tabular}

Based on Table 1, the highest achievement of $97 \%$ is achieved by only one student. Two students achieved grade E, namely $27 \%$ and $37 \%$. This is categorized as "Has Not Achieved Minimum Level".

The achievement of students using multimedia materials individually (Class 2A2) 
The Distribution of Individual Pre Test Scores (Table 2)

\begin{tabular}{|c|c|c|c|}
\hline ITEM & $\begin{array}{l}\text { Number of } \\
\text { Students }\end{array}$ & PERCENTAGE/ACHIEVEMENT & GRADE \\
\hline 1 & 1 & $88 \%$ & A \\
\hline 2. & 1 & $85 \%$ & A \\
\hline 3. & 1 & $80 \%$ & A \\
\hline 5 & 2 & $78 \%$ & $\mathrm{~B}$ \\
\hline 6 & 1 & $71 \%$ & $\mathrm{~B}$ \\
\hline 7 & 1 & $70 \%$ & $\mathrm{~B}$ \\
\hline 8 & 1 & $68 \%$ & $\mathrm{~B}$ \\
\hline 9 & 2 & $66 \%$ & $\mathrm{~B}$ \\
\hline 10 & 1 & $65 \%$ & $\mathrm{~B}$ \\
\hline 11 & 1 & $62 \%$ & $B$ \\
\hline 12 & 1 & $61 \%$ & $\mathrm{~B}$ \\
\hline 13 & 1 & $60 \%$ & $\mathrm{~B}$ \\
\hline 11 & 1 & $57 \%$ & $\mathrm{C}$ \\
\hline 12 & 2 & $55 \%$ & C \\
\hline 13 & 2 & $54 \%$ & $C$ \\
\hline 14 & 1 & $52 \%$ & $C$ \\
\hline 15 & 1 & $51 \%$ & $C$ \\
\hline 16 & 2 & $50 \%$ & $C$ \\
\hline 17 & 1 & $41 \%$ & $D$ \\
\hline 18 & 1 & $34 \%$ & $E$ \\
\hline 19 & 1 & $27 \%$ & $E$ \\
\hline 20 & 1 & $26 \%$ & $E$ \\
\hline 26 & 1 & $27 \%$ & $E$ \\
\hline
\end{tabular}

Based on Table 2, the descriptive statistics of individual percentage of achievements of the first respondent is $88 \%$, followed by second respondent $85 \%$ and the third with $80 \%$. They have obtained the "Excellent" level of achievement with grade A. The following respondents scored $78 \%, 71 \%, 70 \%, 68 \% 66 \%$ and $65 \%$ which falls into grade $\mathrm{B}$; at the achievement level of "Good". The next group of respondents obtained "Average" level of achievement with Grade C with; 62\%, 61\%, 60\%, 57\%, 55\%, 54\%, 52\%, 51\% and $50 \%$. The other 4 students managed to obtain Grade E; "Has Not Achieved Minimum Level"

The achievement of students using multimedia materials individually (Class 2A3) 
The Distribution of Individual Pre Test Scores (Table 3)

\begin{tabular}{|l|c|c|c|}
\hline Item & Number of Students & PERCENTAGE/ACHIEVEMENT & GRADE \\
\hline 1 & 1 & $78 \%$ & $\mathrm{~B}$ \\
\hline 2. & 2 & $70 \%$ & $\mathrm{~B}$ \\
\hline 3. & 2 & $68 \%$ & $\mathrm{~B}$ \\
\hline 6 & 1 & $58 \%$ & $\mathrm{C}$ \\
\hline 7 & 1 & $54 \%$ & $\mathrm{C}$ \\
\hline 8 & 1 & $52 \%$ & $\mathrm{C}$ \\
\hline 9 & 1 & $50 \%$ & $\mathrm{C}$ \\
\hline 10 & 2 & $48 \%$ & $\mathrm{D}$ \\
\hline 11 & 5 & $46 \%$ & $\mathrm{D}$ \\
\hline 12 & 2 & $44 \%$ & $\mathrm{D}$ \\
\hline 13 & 2 & $42 \%$ & $\mathrm{D}$ \\
\hline 14 & 1 & $40 \%$ & $\mathrm{E}$ \\
\hline 15 & 3 & $38 \%$ & $\mathrm{E}$ \\
\hline 16 & 2 & $36 \%$ & $\mathrm{E}$ \\
\hline 17 & 2 & $26 \%$ & $\mathrm{E}$ \\
\hline 29 & 2 & $22 \%$ & \\
\hline & $\begin{array}{l}\text { Total number of } \\
\text { Students }=\end{array}$ & Average Percentage of & \\
& 30 & Achievement $=28 \%$ & \\
\hline
\end{tabular}

Table 3 shows the achievement levels of 2A3 class students. 5 respondents obtained Grade B; achieving "Good". Meanwhile, 4 students obtained "Satisfactory" achievement level. This is followed by, 12 respondents in Grade D with a "Achieved Minimum Level". The other 11 students obtained Grade E; "Has Not Achieved Minimum Level"

\section{B. Data Analysis of Achievement of Students who used multimedia materials in Cooperative Learning (Group)}

A. Group Marks: Effectiveness Test in Using Audio Visual in Teaching and Learning of Kadazandusun Language ( Kelas 2 A1) (Table 4)

\begin{tabular}{|c|c|}
\hline Name of Groups & Marks/Grades \\
\hline A to C & $86 / \mathrm{A}$ \\
\hline Kosumandakan & $92 / \mathrm{A}$ \\
\hline Lokos & $82 / \mathrm{B}$ \\
\hline Linumis HJL & $94 / \mathrm{A}$ \\
\hline Bambarayon & $81 / \mathrm{A}$ \\
\hline Turungou' & $76 / \mathrm{B}$ \\
\hline E'S & $88 / \mathrm{A}$ \\
\hline
\end{tabular}


Table 4 shows that there is an $85 \%$ of achievement through cooperative learning, which is in "Excellent" level. This involves 6 out of 7 groups. Only one group obtained 76\%; at "Satisfactory" level.

Group Marks: Effectiveness Test in Using Audio Visual in Teaching and Learning of Kadazandusun Language ( Kelas 2 A2) (Table 5)

\begin{tabular}{|c|c|}
\hline Name of Groups & Marks/Grades \\
\hline Mataub & $88 / \mathrm{A}$ \\
\hline Totopis & $83 / \mathrm{A}$ \\
\hline Turipos & $82 / \mathrm{A}$ \\
\hline Kolumpisau & $78 / \mathrm{B}$ \\
\hline Huminodun & $87 / \mathrm{A}$ \\
\hline Jimy & $86 / \mathrm{A}$ \\
\hline
\end{tabular}

Table 5 shows that 5 out 6 groups obtained Grade A , which is "Excellent" achievement level. The group Mataub obtained the highest marks 88\% (Grade A); "Excellent" level. Meanwhile, Huminodum group obtained 78\% (Grade B); achieving "Satisfactory" achievement level.

Group Marks: Effectiveness Test in Using Audio Visual in Teaching and Learning of Kadazandusun Language ( Kelas 2 A3) (Table 6)

\begin{tabular}{|c|c|c|c|}
\hline Item & GROUPS & PERCENTAGE/ACHIEVMENT & GRADE \\
\hline 1 & Group 1 & $56 \%$ & C \\
\hline 2 & Group 2 & $54 \%$ & C \\
\hline 3 & Group 3 & $54 \%$ & C \\
\hline 4 & Group 4 & $52 \%$ & $\mathrm{C}$ \\
\hline 5 & Group 5 & $46 \%$ & $\mathrm{D}$ \\
\hline 6 & Group 6 & $42 \%$ & $\mathrm{D}$ \\
\hline & $\begin{array}{c}\text { Total Number of Groups }= \\
6\end{array}$ & $\begin{array}{c}\text { Average Percentage of } \\
\text { Achievement }=50.6 \%\end{array}$ & \\
\hline
\end{tabular}

Table 6 shows that 4 out of 6 groups achieved Grade C; "Satisfactory" achievement level. Two other groups obtained Garde D, and fall into the category of "Has Not Achieved Minimum Level". 


\section{Overall graph to compare marks obtained by individuals and groups using multimedia materials.}

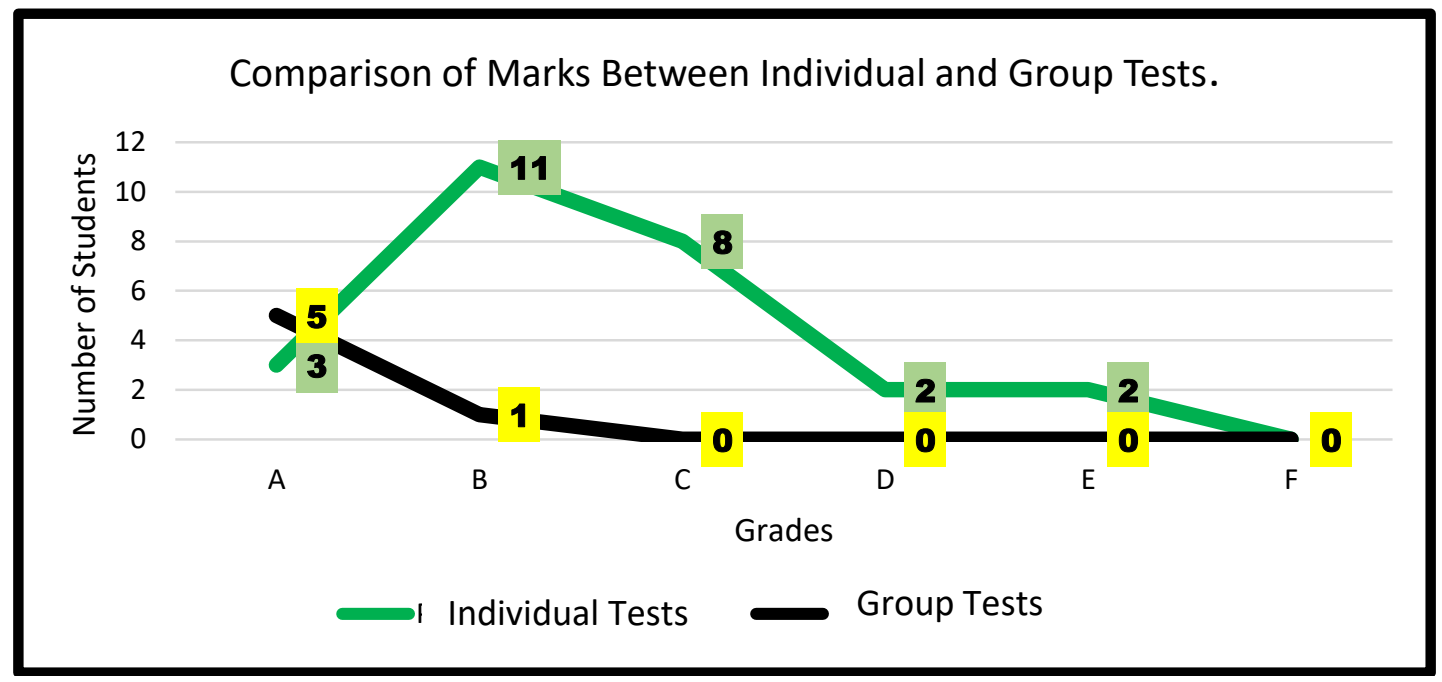

\section{Suggestions}

The Kadazandusun language curriculum developers can improve the quality of curriculum developed significantly. This is because cooperative learning, assisted by multimedia materials prepares an effective learning application which consists of approaches, strategies, methods and, effective teaching and learning techniques. This takes place with the blending of learning across Kadazandusun Language, and Information Technology and Communication curriculums.

Malaysian Education Ministry (MOE)- Implementing a policy to build a Kadazandusun language software package in accordance to cooperative, collaborative, contextual, and interactive constructivism learning approaches.

Teachers and Lecturers should add more teaching materials especially fro Kadazandusun Language to attract students from various ethnics to learn the language.

Further Research- as references to assist future studies.

\section{Contribution of the Study}

This study provides a very significant academic contribution to cooperative teaching and learning with the help of multimedia elements. It thus provides an alternative approach to Kadazandusun language teachers through cooperative learning, discussion and interaction between students as well as helping one another especially for disadvantaged students. Therefore, teacher intervention is less necessary as students can cooperatively improve their understanding of the subject matter. In addition, the implication of the research shows that cooperative learning, assisted by multimedia elements consist of leadership practices with social skills, besides practicing respect and responsibility. This is especially highlighted by students with higher level skills, by leading and guiding the group members. This is not the 
case in individual learning; as the understanding of the delivered information depends completely on the reasoning of the students themselves.

\section{Conclusion}

Based in the data analysis, it can be concluded that cooperative learning which is assisted by multimedia elements could contribute to the improvement in students' achievements compared to the individual learning. In general, the usage of audio visuals in the teaching and learning of Kadazandusun Language provides strength or positive effect in cooperative learning compared to individual learning method as following:

a. Students are able to exchange opinions regarding topics learnt. This does not take place in individual test because the information delivered depends completely on the understanding of students.

b. The practice of leadership skills in small groups is highlighted, especially among students highly skilled to lead and to guide the members of their groups.

c. Students who are not able to understand teachers' instructions, and those who are unable to understand the needs of a task have the opportunity to seek explanations from their friends.

It is evident that the usage of audio visual in the teaching and learning of Kadazandusun Language helps students to understand and master topics discussed. It can be concluded that cooperative learning with the help of multimedia can help students to develop a more advanced learning style with multimedia aspects. Students have the opportunity to experience a different learning environment from the existing ones. The cooperative use of ICT in the PdP process is more fun with the multimedia element and enables students to better understand the content of the learning rather than individual learning. By applying this theory of constructivism, it enables students to become actively involved in the cooperative teaching and learning process. Students build their knowledge by testing their ideas and approaches based on existing knowledge and experiences, applying new situations and integrating new knowledge gained with existing intellectual construction based on multimedia elements. Cooperative learning methods can improve performance in each of the groups studied. It is suggested that the teaching of multimedia-based Kadazandusun language subjects can be implemented through cooperative learning methods.

\section{Acknowledgment}

This paper is based on the research project entitled Pencapaian Pembelajaran Koperatif dan Pembelajaran Secara Individu Terhadap Mata Pelajaran Bahasa Kadazandusun Berbantukan Elemen Multimedia Di Peingkat Menengah Rendah. The authors would like to extend their gratitude to the Research Management and Innovation Centre (RMIC), Sultan Idris Education University (UPSI) for the University Research Grants (code: 2018-0009-107-01)( GPU Pendidikan) that helped fund the research.

\section{References}

Ahmed, U., Majid, A. H. A., \& Zin, M. L. M. (2016). HR Moderating HR: Critical link between Developmental HR Practices and work engagement in a Moderated Model. Management Review: An International Journal, 11(2), 4-22. 
Ahmed, U., Umrani, W. A., Qureshi, M. A., \& Samad, A. (2018). Examining the links between teachers support, academic efficacy, academic resilience, and student engagement in Bahrain. International Journal of Advanced and Applied Sciences, 5(9), 39-46.

Ahmed, U., Isa, N. M., Majid, A. H. A., Zin, M. L. M., \& Amin, B. M. (2017). Towards understanding work engagement: can HR really buffer HR? Test of a moderated model. International Journal of Economic Research, 14(20), 1-18.

Bates, A. W. (2006). Managing Technological Change. Jossey-Bass: San Francisco.

Israel, G. D. (2013). Determining Sample Size, Program Evaluation and Organizational Development, IFAS Ektension, University of Florida. PEOD-6. June.

Harun, J., \& Tasir, Z. (2003). Multimedia Dalam Pendidikan. Pahang: PTS Publication \& Distributors.

Luaran, J. (2010) Penggunaan Pakej Pembelajaran WEDPI Dalam Membantu Penguasaan Praktis Aplikasi Teknologi Maklumat. Tesis Doktor Falsafah: Universiti Malaysia Sabah

Taisin, J. N. (2016). Keberkesanan Kaedah Pengajaran dan Pembelajaran Bahasa Kadazandusun Dalam Kalangan Guru Bahasa Kadazandusun Sekolah Rendah di Daerah Ranau Sabah: Satu Tinjauan Awal. Geran Penyelidikan Universiti: Universiti Pendidikan Sultan Idris

Kagan, S. (2006). Cooperative learning and sociological Factor in schooling. In Carlos Cortes (Ed.) Beyond Language: Social and Cultural Factors in Schooling Language Minority Students. Los Angeles, Ca: California State University Evaluation, Dissemination and Assessment Center.

Kementerian Pendidikan Malaysia. (2016). Sukatan Pelajaran Bahasa Melayu Sekolah Menengah. Kuala Lumpur: Pusat Perkembangan Kurikulum.

Ghafar, M. N. A. (2003). Reka Bentuk Tinjauan Soal Selidik Pendidikan. Skudai: Universiti Teknologi Malaysia.

Tassan, T. (2011). Hubungan antara Kesediaan dengan Sikap dan Kemahiran Guru Bahasa Kadazandusun terhadap penggunaan pakej perisian: Satu Tinjauan Di Sekolah Rendah. Tesis Sarjana: Universiti Malaysia Sabah

Etnik, U. B. (2010). Data Bahasa Iban Sekolah Rendah dan Sekoah Menengah Mengikut Daerah di Sarawak. Putrajaya: Bahagian Pembangunan Kurikulum, Kementerian Pelajaran Malaysia 